\title{
Applicability of scoring systems predicting outcome of transarterial chemoembolization for hepatocellular carcinoma
}

\author{
Marie Vogeler ${ }^{1,7} \cdot$ Isabelle Mohr $^{1,7} \cdot$ Jan Pfeiffenberger ${ }^{1,7} \cdot$ Simon David Sprengel ${ }^{2}$. Miriam Klauss ${ }^{2}$. \\ Andreas Teufel ${ }^{6,7} \cdot$ De-Hua Chang ${ }^{2,7} \cdot$ Christoph Springfeld ${ }^{3,7} \cdot$ Thomas Longerich $^{4,7}$. Uta Merle ${ }^{1,7}$. \\ Arianeb Mehrabi $^{5,7} \cdot$ Karl Heinz Weiss $^{1,7} \cdot$ Markus Mieth $^{5,7}$ (])
}

Received: 25 November 2019 / Accepted: 20 January 2020 / Published online: 27 February 2020

(c) The Author(s) 2020

\begin{abstract}
Purpose Several scoring systems have been proposed to predict the outcome of transarterial chemoembolization (TACE) in patients with hepatocellular carcinoma (HCC). However, the application of these scores to a bridging to transplant setting is poorly validated. Evaluation of the applicability of prognostic scores for patients undergoing TACE in palliative intention vs. bridging therapy to liver transplantation (LT) is necessary.

Methods Between 2008 and 2017, 148 patients with HCC received 492 completed TACE procedures (158 for bridging to transplant; 334 TACE procedures in palliative treatment intention at our center and were analyzed retrospectively. Scores (ART, CLIP, ALBI, APRI, SNACOR, HAP, STATE score, Child-Pugh, MELD, Okuda and BCLC) were calculated and evaluated for prediction of overall survival. ROC analysis was performed to assess prediction of 3-year survival and treatment discontinuation.

Results In patients receiving TACE in palliative intention most scores predicted OS in univariate analysis but only mSNACOR score $(p=0.006)$, State score $(p<0.001)$ and Child-Pugh score $(p<0.001)$ revealed statistical significance in the multivariate analysis. In the bridging to LT cohort only the BCLC score revealed statistical significance $(p=0.002)$.

Conclusions Clinical usability of suggested scoring systems for TACE might be limited depending on the individual patient cohorts and the indication. Especially in patients receiving TACE as bridging to LT none of the scores showed sufficiently applicability. In our study Child-Pugh score, STATE score and mSNACOR score showed the best performance assessing OS in patients with TACE as palliative therapy.
\end{abstract}

Keywords TACE $\cdot$ Embolization $\cdot$ Liver cancer $\cdot$ Stage migration

\section{Abbreviations}

TACE Transarterial chemoembolization

HCC Hepatocellular carcinoma

Marie Vogeler and Isabelle Mohr contributed equally.

Markus Mieth

Markus.mieth@med.uni-heidelberg.de

1 Internal Medicine IV, Heidelberg University Hospital, Heidelberg, Germany

2 Department of Radiology, Heidelberg University Hospital, Heidelberg, Germany

3 Department of Medical Oncology, Heidelberg University Hospital, National Center for Tumor Diseases (NCT), Heidelberg, Germany

4 Department of Pathology, Heidelberg University Hospital, Heidelberg, Germany
LT Liver transplantation

CLIP Cancer of the Liver Italian Program

ART Assessment for retreatment with transarterial chemoembolization

ALBI Albumin-bIlirubin grade for HCC

5 Department of General, Visceral and Transplantation Surgery, Heidelberg University Hospital, INF 110, 69120 Heidelberg, Germany

6 Division of Hepatology, Department of Medicine II, Medical Faculty Mannheim, Heidelberg University, Mannheim, Germany

7 Liver Cancer Center Heidelberg (LCCH), Heidelberg University Hospital, Heidelberg, Germany 


$\begin{array}{ll}\text { APRI } & \begin{array}{l}\text { AST to platelet ratio index } \\ \text { SNACOR } \\ \text { pumor size and number, baseline alpha-feto- } \\ \text { protein, child-pugh and objective radiological } \\ \text { response }\end{array} \\ \text { HAP } & \begin{array}{l}\text { Hepatoma arterial-embolisation prognostic } \\ \text { score }\end{array} \\ \text { STATE } & \begin{array}{l}\text { Selection for transarterial chemoembolization } \\ \text { treatment }\end{array} \\ \text { MELD } & \begin{array}{l}\text { Model of end stage liver disease } \\ \text { Barcelona clinic liver cancer staging system }\end{array}\end{array}$

\section{Introduction}

Therapeutic approaches to hepatocellular carcinoma (HCC) are multimodal. Management and prognosis of HCC patients highly depends on tumor status, general health and actual liver functional reserve (Cabibbo et al. 2010; Llovet et al. 1999b; Marrero et al. 2005; Okuda et al. 1985). Curative treatments in terms of resection, liver transplantation or local ablation are often restricted to subgroups with preserved liver function and limited tumor load (Bruix and Sherman 2005; Llovet et al. 2005; 2012). For intermediate stage HCC patients, TACE is currently considered (palliative) first line-therapy (Bruix and Sherman 2011; Llovet and Bruix 2003; Llovet et al. 2008) offering local tumor control and prolongation of OS (Arii et al. 2000; Ikai et al. 2004; Lee et al. 2012; Takayasu et al. 2006). Apart from its use in intermediate and advanced tumor stages, another application for TACE is as bridging treatment to liver transplantation (Decaens et al. 2005; Llovet et al. 2012; Kollmann et al. 2017; Majno et al. 1997; Porrett et al. 2006; Bruix et al. 2011). Various scoring systems (Table 1) predicting the prognosis of HCC patients undergoing different therapies are available (Ho et al. 2017; Hucke et al. 2014a, b; Kadalayil et al. 2013; Kamath et al. 2001; Kim et al. 2016; Li et al. 2016; Marrero et al. 2005; Cancer of the Liver Italian Program (CLIP) Investigators 1998; Okuda et al. 1985; Sawhney et al. 2011; Song et al. 2016; Yin et al. 2016), to guide treatment decisions, like e.g., the commonly used BCLC classification (Cillo et al. 2006; Guglielmi et al. 2008; Llovet et al. 1999a, 2008,2012; Marrero et al. 2005; Vitale et al. 2009). In the setting of TACE a considerable number of scores, such as Child-Pugh (Child and Turcotte 1964; Pugh et al. 1973), ALBI (Johnson et al. 2015), APRI (Song et al. 2016; Wai et al. 2003), HAP (Kadalayil et al. 2013), ART (Sieghart et al. 2013), CLIP (Cancer of the Liver Italian Program Investigators 1998), SNACOR (Kim et al. 2016), MELD (Kamath et al. 2001; Sawhney et al. 2011), Okuda (Okuda et al. 1985) and STATE (Hucke et al. 2014a) aim to predict prognosis of HCC patients undergoing therapy. But especially data on a bridging to transplant collective or comparative data between scores are sparse. The current study retrospectively assessed the proposed scoring systems in HCC patients eligible for TACE for bridging to transplant or in palliative.

\section{Materials and methods}

\section{Study design}

The retrospective cohort study was conducted in a tertiary care center (Heidelberg University Hospital) and was a priori approved by the institutional review board (IRB). Data collection was based on chart review. We included patients with established diagnosis of hepatocellular carcinoma according EASL criteria, who received at least one TACE as a therapy of HCC between 2011 and 2017 in our center (Llovet et al. 2012). Decision for TACE treatment and modality of beads (DEB-TACE, conventional TACE or TACE with biodegradable Particles) was in all cases assessed by a multidisciplinary tumor board. The boards treatment approach followed the current EASLEORTC Clinical Practice Guidelines (Llovet et al. 2012) in patients who have unresectable lesions and are not suitable to receive other ablative therapies. Patients who had been diagnosed as BCLC stage A, C or D, but were unable or unwilling to receive the proposed therapy (e.g., LT, RF, Sorafenib) were also eligible for TACE therapy. For patients on the liver transplantation list TACE was considered standard bridging treatment.

\section{Subgroup definition}

Each TACE procedure of the included patients was categorized in two different subgroups, depending on the treatment plan at the time of TACE therapy (Fig. 1): Bridging to transplant or palliative therapy. The bridging to LT dataset included all interventions in which patients were enrolled on the transplant waiting list at time of TACE, regardless of whether the LT was performed afterwards. The palliative dataset consisted of interventions performed in patients who did not meet the criteria for a liver transplant at the time of TACE.

\section{Calculation of scores}

Scores were calculated at each TACE session. Score calculation was done according to their original formula. In addition, we calculated a modified SNACOR (mSNACOR) score and modified ART (mART) score. The original calculation of these two scores only includes parameters in comparison to the first TACE to assess whether a second TACE should be performed. To assess these scores with respect to each individual 
Table 1 Assessed scores in this study

\begin{tabular}{|c|c|c|c|c|}
\hline Score & Included variables & $\begin{array}{l}\text { Prognostic groups } \\
\text { identified by the score }\end{array}$ & Median OS (months) ${ }^{b}$ & References \\
\hline \multirow[t]{5}{*}{ BCLC (Biolato 2014) } & ECOG score & A (early stage) & $18.3-76.2$ & $\begin{array}{l}\text { Abbasi et al. (2017), Allgaier } \\
\text { et al. (1998) and Arii (2000) }\end{array}$ \\
\hline & Number and diameter & B (intermediate stage) & $15.1-24$ & $\begin{array}{l}\text { Abbasi et al. (2017), Allgaier } \\
\text { et al. (1998) and Arii (2000) }\end{array}$ \\
\hline & $\begin{array}{l}\text { Vascular invasion and metas- } \\
\text { tasis }\end{array}$ & $\mathrm{C}$ (advanced stage) & $9-13.7$ & $\begin{array}{l}\text { Abbasi et al. (2017), Allgaier } \\
\text { et al. (1998) and Arii (2000) }\end{array}$ \\
\hline & Child-Pugh score & D (terminal stage) & $4-5.4$ & $\begin{array}{l}\text { Abbasi et al. (2017), Allgaier } \\
\text { et al. (1998) and Arii (2000) }\end{array}$ \\
\hline & Okuda score & & & $\begin{array}{l}\text { Abbasi et al. (2017), and Arii } \\
\text { (2000) }\end{array}$ \\
\hline \multirow[t]{5}{*}{$\begin{array}{l}\text { Child-Pugh (Child and } \\
\text { Turcotte 1964, Cholongitas } \\
\text { et al. 2005) }\end{array}$} & Serum albumin & $A=5-6$ points & $18.3-104$ & $\begin{array}{l}\text { Abbasi et al. (2017), Arii } \\
\text { (2000), Bruix and Sherman } \\
\text { (2005), Bruix et al. (2011), } \\
\text { Bruns et al. (2014) and } \\
\text { Cabibbo et al. (2010) }\end{array}$ \\
\hline & INR & $\mathrm{B}=7-9$ points & $11.8-46$ & $\begin{array}{l}\text { Arii (2000), Bruix and Sher- } \\
\text { man (2005), Bruix et al. } \\
\text { (2011), Bruns et al. (2014) } \\
\text { and Cabibbo et al. (2010) }\end{array}$ \\
\hline & Ascites & $\mathrm{C} \geq 10$ points & $4-23.8$ & $\begin{array}{l}\text { Arii (2000), Bruix and Sher- } \\
\text { man (2005), Bruns et al. } \\
\text { (2014) and Cabibbo et al. } \\
\text { (2010) }\end{array}$ \\
\hline & Encephalopathy & & & \\
\hline & Total bilirubin & & & \\
\hline \multirow[t]{3}{*}{ ART (Abbasi et al. 2017) } & Child-Pugh score & Low risk $<2.5$ points & $23.1-104$ & $\begin{array}{l}\text { Abbasi et al. (2017), } \\
\text { Bruix et al. (2011), Cillo } \\
(2004,2006)\end{array}$ \\
\hline & Radiologic tumor response & High risk $\geq 2.5$ points & $5.4-25$ & $\begin{array}{l}\text { Abbasi et al. (2017), } \\
\text { Bruix et al. (2011), Cillo } \\
(2004,2006)\end{array}$ \\
\hline & AST & & & \\
\hline \multirow[t]{4}{*}{$\begin{array}{l}\text { HAP (Dhanasekaran et al. } \\
\text { 2010) }\end{array}$} & AFP & $\mathrm{A}=0$ points & $25.5-n . r$. & $\begin{array}{l}\text { Bruix et al. (2011), Cabibbo } \\
\text { et al. (2010), Cillo (2004), } \\
\text { Dhanasekaran et al. (2010), } \\
\text { Durand and Valla (2008) } \\
\text { and Llovet et al. (2012) }\end{array}$ \\
\hline & Serum albumin & $\mathrm{B}=1$ point & $18.1-55.0$ & $\begin{array}{l}\text { Bruix et al. (2011), Cabibbo } \\
\text { et al. (2010), Cillo (2004), } \\
\text { Dhanasekaran et al. (2010), } \\
\text { Durand and Valla (2008) } \\
\text { and Llovet et al. (2012) }\end{array}$ \\
\hline & Total bilirubin & $\mathrm{C}=2$ points & $8.9-46.0$ & $\begin{array}{l}\text { Bruix et al. (2011), Cabibbo } \\
\text { et al. (2010), Cillo (2004), } \\
\text { Dhanasekaran et al. (2010), } \\
\text { Durand and Valla (2008) } \\
\text { and Llovet et al. (2012) }\end{array}$ \\
\hline & Diameter & $\mathrm{D} \geq$ points & $3.6-18$ & $\begin{array}{l}\text { Bruix et al. (2011), Cabibbo } \\
\text { et al. (2010), Cillo (2004), } \\
\text { Dhanasekaran et al. (2010), } \\
\text { Durand and Valla (2008) } \\
\text { and Llovet et al. (2012) }\end{array}$ \\
\hline
\end{tabular}


Table 1 (continued)

\begin{tabular}{|c|c|c|c|c|}
\hline Score & Included variables & $\begin{array}{l}\text { Prognostic groups } \\
\text { identified by the score }\end{array}$ & Median OS (months) ${ }^{\mathrm{b}}$ & References \\
\hline \multirow[t]{3}{*}{$\begin{array}{l}\text { STATE (El Khaddari et al. } \\
\text { 2002) }\end{array}$} & CRP & Low risk $\geq 18$ points & $19.5-22.2$ & $\begin{array}{l}\text { El Khaddari et al. (2002), } \\
\text { Farinati et al. (2000) and } \\
\text { Georgiades et al. (2006) }\end{array}$ \\
\hline & Up-to-seven criteria & High risk $<18$ points & $5.3-14.3$ & $\begin{array}{l}\text { El Khaddari et al. (2002), } \\
\text { Farinati et al. (2000) and } \\
\text { Georgiades et al. (2006) }\end{array}$ \\
\hline & Serum albumin & & & \\
\hline \multirow{2}{*}{$\begin{array}{l}\text { APRI (Guglielmi et al. 2008, } \\
\text { Hinrichs 2017) }\end{array}$} & Platelet count & $\leq 1.15^{\mathrm{a}}$ & $(-)$ & \\
\hline & AST & $>1.15^{\mathrm{a}}$ & $(-)$ & \\
\hline \multirow[t]{3}{*}{ ALBI } & Total bilirubin & $\mathrm{A} 1 \leq-2.6$ & 28.9-38.9 & $\begin{array}{l}\text { Cabibbo et al. (2010), Ho } \\
\text { (2017) }\end{array}$ \\
\hline & Serum albumin & $\mathrm{A} 2>-2.6 \leq-1.39$ & $10.2-22.4$ & $\begin{array}{l}\text { Cabibbo et al. (2010), Ho } \\
\text { (2017) and Hucke (2014a) }\end{array}$ \\
\hline & & A3 $>-1.39$ & $6.05-15.3$ & $\begin{array}{l}\text { Cabibbo et al. (2010) and } \\
\text { Hucke (2014a) }\end{array}$ \\
\hline \multirow[t]{4}{*}{$\begin{array}{l}\text { SNACOR (Hucke et al. } \\
\text { 2014b) }\end{array}$} & Number and Diameter & Low risk $0-2$ points & $31.5-49.8$ & $\begin{array}{l}\text { Hucke et al. (2014b) and Ikai } \\
\text { (2004) }\end{array}$ \\
\hline & AFP & Interm. risk $3-6$ points & $19.9-30.7$ & $\begin{array}{l}\text { Hucke et al. (2014b) and Ikai } \\
\text { (2004) }\end{array}$ \\
\hline & Child-Pugh class & High risk $7-10$ points & $9.2-12.4$ & $\begin{array}{l}\text { Hucke et al. (2014b) and Ikai } \\
\text { (2004) }\end{array}$ \\
\hline & Radiologic tumor response & & & \\
\hline \multirow[t]{5}{*}{ CLIP (Kadalayil 2013) } & AFP & $0=0$ points & $31-68.7$ & $\begin{array}{l}\text { Arii (2000), Bruix and Sher- } \\
\text { man (2005), Bruns et al. } \\
\text { (2014) and Johnson (2015) }\end{array}$ \\
\hline & Portal vein thrombosis & $1=1$ point & $27-43.8$ & $\begin{array}{l}\text { Arii (2000), Bruix and Sher- } \\
\text { man (2005), Bruns et al. } \\
\text { (2014) and Johnson (2015) }\end{array}$ \\
\hline & Child-Pugh class & $2=2$ points & $13-26.4$ & $\begin{array}{l}\text { Arii (2000), Bruix and Sher- } \\
\text { man (2005), Bruns et al. } \\
\text { (2014) and Johnson (2015) }\end{array}$ \\
\hline & Number and diameter & $3=3$ points & $8-15.0$ & $\begin{array}{l}\text { Arii (2000), Bruix and Sher- } \\
\text { man (2005), Bruns et al. } \\
\text { (2014) and Johnson (2015) }\end{array}$ \\
\hline & & $4 \geq 4$ points & $2-3.3$ & $\begin{array}{l}\text { Arii (2000), Bruix and Sher- } \\
\text { man (2005), Bruns et al. } \\
\text { (2014) }\end{array}$ \\
\hline \multirow[t]{4}{*}{ Okuda (Kamath 2001) } & Tumor size & $\mathrm{I}=0$ points & $27-45.5$ & $\begin{array}{l}\text { Arii (2000), Bruix and Sher- } \\
\text { man (2005), Bruns et al. } \\
\text { (2014) and Johnson (2015) }\end{array}$ \\
\hline & Ascites & $\mathrm{II}=1-2$ points & $10-21$ & $\begin{array}{l}\text { Arii (2000), Bruix and Sher- } \\
\text { man (2005), Bruns et al. } \\
\text { (2014) and Johnson (2015) }\end{array}$ \\
\hline & Albumin & $\mathrm{III}=3-4$ points & $2-16$ & $\begin{array}{l}\text { Arii (2000), Bruix and Sher- } \\
\text { man (2005), Bruns et al. } \\
\text { (2014) and Johnson (2015) }\end{array}$ \\
\hline & Bilirubin & & & \\
\hline \multirow{2}{*}{$\begin{array}{l}\text { MELD (Kim 2016; Kollmann } \\
\text { et al. 2017) }\end{array}$} & INR & $<10$ & $(-)$ & \\
\hline & Creatinine & $\geq 10$ & $(-)$ & \\
\hline
\end{tabular}

${ }^{a}$ Cut-off value concerning liver function deterioration after TACE

${ }^{\mathrm{b}}$ Calculated in cohorts in which a minimum of $50 \%$ of the included patients were treated with TACE

(-)No information found about median OS with this cut-off value (in cohorts with a minimum of 50\% TACE-treated patients) 
TACE, these parameters were calculated in comparison to the previous TACE instead to the first TACE.

\section{Statistics}

Statistical analysis was performed using SPSS-25 software (IBM, Germany). The two-tailed Chi-squared was employed to compare categorical data of bridging dataset to palliative dataset. The Mann-Whitney $U$ test was used for continuous variables. The primary endpoint was overall survival concerning the different scores, analyzed by Kaplan-Meier method and compared by log rank test. Significant scoring systems in the univariate analysis were introduced to multivariate Cox regression model to determine the adjusted risk ratio. The ROC analysis examines which score reflects best probability of achieving 3-year survival or probability of treatment discontinuation due to adverse events or death. 3-years survival was calculated from the time of each individual TACE. Statistical significance was set at $p$ value $<0.05$ in two-tailed tests.

\section{Results}

\section{Patient characteristics and distribution of scores at TACE procedures}

A total of 492 TACE sessions were included in this study (158 bridging/334 palliative sessions). In consequence of listing criteria, patients in the bridging cohort were younger, had a limited tumor disease and different tumor properties, such as less frequent portal or hepatic vein infiltration and no extrahepatic tumor manifestation. In the palliative dataset, $28(8.4 \%)$ procedures were performed as conventional TACE with Carboplatin or Doxorubicin as chemotherapeutic agent combined with Lipiodol ${ }^{\circledR}$, which is only half as common as in the bridging dataset. In the palliative group $73(21.9 \%)$ TACE sessions were performed in patients who finally discontinued TACE therapy (and received no further local therapy) because of adverse events or death, whereas in the bridging dataset none of the patients discontinued the TACE therapy (Table 2). Median overall survival after TACE was not reached in the bridging dataset due to LT and was 21.8 months in the palliative dataset (Table 4). The descriptive comparative analysis of the scoring systems between both datasets is thus confounded by the different baseline characteristics and showed significant distinct distributions of the scoring values (BCLC stage, Child-Pugh

Fig. 1 Study population

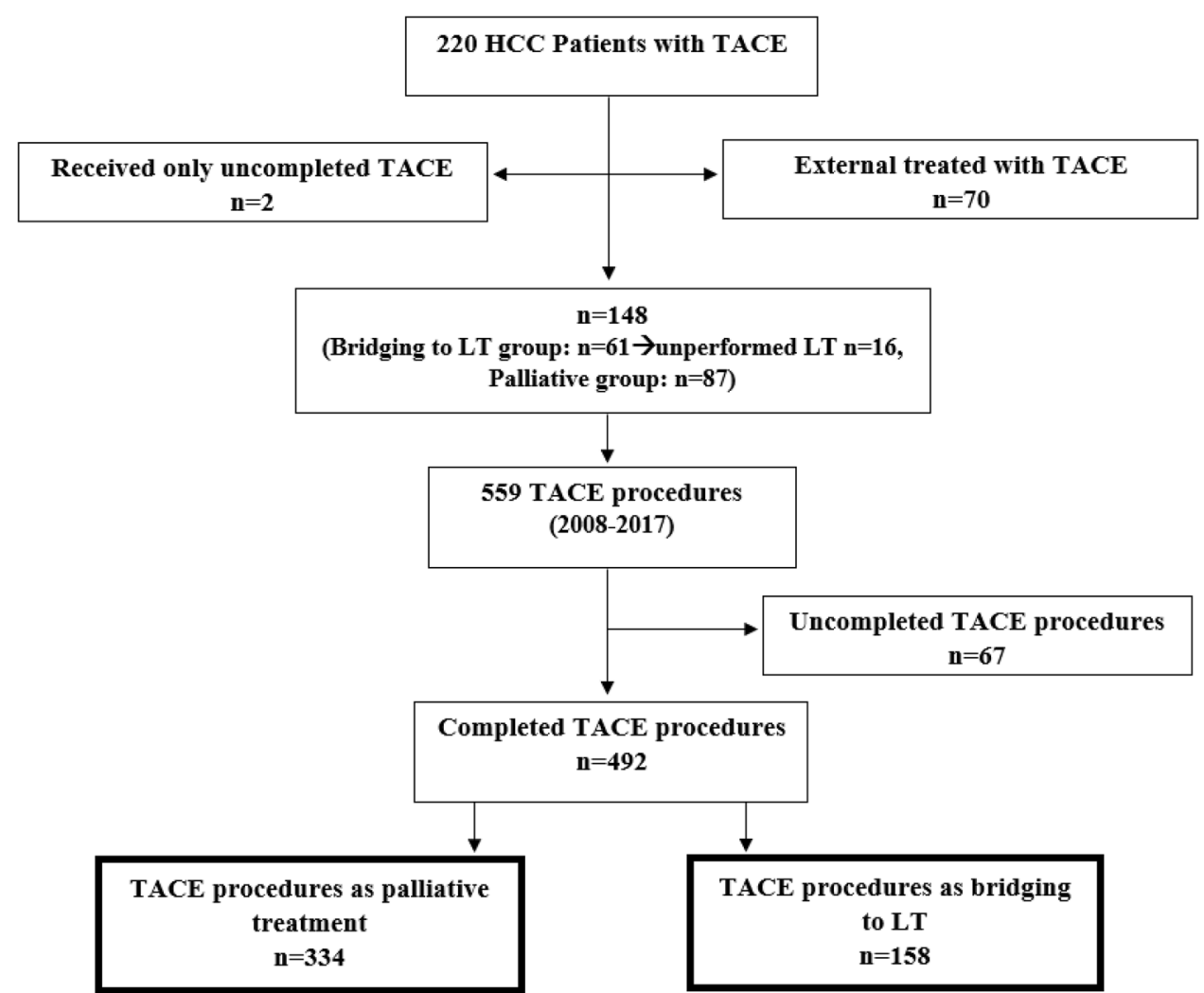


Table 2 Patient characteristics at TACE procedures in different subgroups

\begin{tabular}{|c|c|c|c|c|c|}
\hline \multirow[t]{2}{*}{ Patient characteristics at TACE procedures } & \multicolumn{2}{|c|}{ Bridging dataset } & \multicolumn{2}{|c|}{ Palliative dataset } & \multirow[t]{2}{*}{$p$} \\
\hline & $N(\%)$ & Total $(N)$ & $N(\%)$ & Total $(N)$ & \\
\hline Number of all TACE procedures & $158(100)$ & & $334(100)$ & & \\
\hline Age (years) (median, range) & $57(28-70)$ & 158 & $71(49-90)$ & 334 & $<0.001$ \\
\hline \multicolumn{6}{|l|}{ Gender } \\
\hline Male & $127(80.4)$ & 158 & 249 (74.6) & 334 & 0.155 \\
\hline Female & $31(19.6)$ & & $85(25.4)$ & & \\
\hline \multicolumn{6}{|l|}{ Number of tumor nodules } \\
\hline Single tumor nodule & $61(38.6)$ & 158 & $64(19.2)$ & 334 & $<0.001$ \\
\hline$>1$ tumor nodule & $97(61.4)$ & & $270(80.8)$ & & \\
\hline Max. diameter, $\mathrm{cm}$ (median, range) & $2.3(0.9-5.0)$ & 158 & $4.6(0.6-19.3)$ & 334 & $<0.001$ \\
\hline Liver vein infiltration & $0(0)$ & 158 & $7(2.1)$ & 334 & 0.067 \\
\hline Portal vein infiltration & $0(0)$ & 158 & $19(5.7)$ & 334 & 0.002 \\
\hline Vena cava infiltration & $0(0)$ & 158 & $3(0.9)$ & 334 & 0.232 \\
\hline Extrahepatic tumor manifestation & $0(0)$ & 158 & $40(12.0)$ & 334 & $<0.001$ \\
\hline \multicolumn{6}{|l|}{ Category of TACE treatment } \\
\hline DEB & $104(65.8)$ & 158 & $244(73.1)$ & 334 & 0.001 \\
\hline Conventional & $32(20.3)$ & & $28(8.4)$ & & \\
\hline Biodegradable & $22(13.9)$ & & $62(18.6)$ & & \\
\hline Additional therapy with sorafenib & $19(12.0)$ & 158 & $16(4.8)$ & 334 & 0.004 \\
\hline $\begin{array}{l}\text { Number of therapy discontinuations (not discontinuations of } \\
\text { TACE procedures) after TACE due to AE or death }\end{array}$ & $0(0)$ & 158 & $73(21.9)$ & 334 & $<0.001$ \\
\hline
\end{tabular}

class, STATE score, HAP stage, SNACOR stage, mSNACOR, ALBI group, CLIP group and MELD score) shown in Table 3. Only the APRI score, Okuda score, mART and the ART score did not differ significantly between the two subgroups (Table 3). Comparing the three most frequent etiologies (viral, alcoholic and cryptogenic/NASH in descending order) in ROC analysis with primary endpoint "3 years survival" and "treatment discontinuation" the scores revealed etiology as a potential confounding factor (Tables 8, 9).

\section{Performance of scores in the palliative dataset}

\section{Median overall survival (OS)}

The univariate Kaplan-Meier analysis in the palliative dataset showed significant differences of median OS in majority of scores (Table 4, Figs. 2, 3). The ART, mART and SNACOR score were the only three scores that showed no significant results in univariate analysis. In multivariate analysis, only three scores were statistically significant independent parameters for the assessment of median OS. These were the Child-Pugh score, the STATE score and the mSNACOR score (which was calculated for each TACE treatment) (Table 4, Fig. 2).

\section{Treatment discontinuation}

The ROC analysis in the palliative group showed that five scores achieved a statistically significant $p$ value concerning the probability of treatment discontinuation due to adverse events or death (Table 6). The Child-Pugh, MELD-, Okuda-, HAP- and ALBI-score achieved a significant $p$ value the AUC values, but did not reach $70 \%$ (Table 6; Fig. 4). The most applicable score to predict the probability of a later TACE discontinuation due to the mentioned circumstances was the Child score (class A versus classes B/C). The number of successfully performed TACE procedures differs significantly ( $p=0.001$; Table 7$)$ in overall survival for the palliative cohort (but not in the bridging collective; $p=0.354$ ).

\section{3-years survival}

The ROC analysis of the database in our study showed that none of the 13 scores had an AUC of over $70 \%$ although some of the scores reached significance in the analysis concerning the probability of achieving a 3-years survival such, e.g., CLIP-, Okuda-, HAP- and Child-Pugh score. The APRI score and MELD score also showed statistically significance in the ROC analysis but none of these scores reached an AUC of $60 \%$ (Table 5; Fig. 5). The most applicable score to predict the probability of achieving 3-years survival was the Okuda score (stage A versus stages B $+\mathrm{C}$ ). As in the 
Table 3 Distribution of scores at TACE procedures in different subgroups

\begin{tabular}{|c|c|c|c|c|c|}
\hline \multirow{2}{*}{$\begin{array}{l}\text { Distribution of scores at } \\
\text { TACE procedures }\end{array}$} & \multicolumn{2}{|c|}{ Bridging dataset } & \multicolumn{2}{|c|}{ Palliative dataset } & \multirow[t]{2}{*}{$p$} \\
\hline & $N(\%)$ & Total $(N)$ & $N(\%)$ & Total $(N)$ & \\
\hline \multicolumn{6}{|l|}{ BCLC stage } \\
\hline A & $103(65.2)$ & \multirow[t]{4}{*}{158} & $52(15.6)$ & \multirow[t]{4}{*}{334} & \multirow[t]{4}{*}{$<0.001$} \\
\hline B & $29(18.4)$ & & $182(54.5)$ & & \\
\hline $\mathrm{C}$ & $4(2.5)$ & & $70(21.0)$ & & \\
\hline $\mathrm{D}$ & $22(13.9)$ & & $30(9.0)$ & & \\
\hline \multicolumn{6}{|l|}{ Child-Pugh class } \\
\hline A & $69(48.9)$ & \multirow[t]{3}{*}{141} & $185(64.9)$ & \multirow[t]{3}{*}{285} & \multirow[t]{3}{*}{0.005} \\
\hline B & $50(35.5)$ & & $75(26.3)$ & & \\
\hline $\mathrm{C}$ & $22(15.6)$ & & $25(8.8)$ & & \\
\hline \multicolumn{6}{|l|}{ STATE score } \\
\hline$\geq 18$ & $131(92.9)$ & \multirow[t]{2}{*}{141} & $200(70.9)$ & \multirow[t]{2}{*}{282} & \multirow[t]{2}{*}{$<0.001$} \\
\hline$<18$ & $10(7.1)$ & & $82(29.1)$ & & \\
\hline \multicolumn{6}{|l|}{ HAP stage } \\
\hline A & $25(18.0)$ & \multirow[t]{4}{*}{139} & $68(25.2)$ & \multirow[t]{4}{*}{270} & \multirow[t]{4}{*}{$<0.001$} \\
\hline B & $42(30.2)$ & & $81(30.0)$ & & \\
\hline $\mathrm{C}$ & $71(51.1)$ & & $89(33.0)$ & & \\
\hline $\mathrm{D}$ & $1(0.7)$ & & $32(11.9)$ & & \\
\hline \multicolumn{6}{|l|}{ mSNACOR stage } \\
\hline Low risk & $21(23.9)$ & 88 & $16(8.2)$ & 195 & $<0.001$ \\
\hline Interm. risk & $67(76.1)$ & & $146(74.9)$ & & \\
\hline High risk & $0(0)$ & & $33(16.9)$ & & \\
\hline SNACOR stage & & & & & \\
\hline Low risk & $11(26.2)$ & 42 & 10 (19.6) & 51 & 0.026 \\
\hline Interm. risk & $31(73.8)$ & & $33(64.7)$ & & \\
\hline High risk & $0(0)$ & & $8(15.7)$ & & \\
\hline ALBI group & & & & & \\
\hline A1 & $34(24.1)$ & 141 & $104(36.7)$ & 283 & 0.003 \\
\hline A2 & 84 (59.6) & & $157(55.5)$ & & \\
\hline A3 & $23(16.3)$ & & $22(7.8)$ & & \\
\hline CLIP group & & & & & \\
\hline 0 & $19(13.7)$ & 139 & $32(11.9)$ & 270 & $<0.001$ \\
\hline 1 & $63(45.3)$ & & $72(26.7)$ & & \\
\hline 2 & $42(30.2)$ & & 88 (32.6) & & \\
\hline 3 & $14(10.1)$ & & 47 (17.4) & & \\
\hline 4 & $1(0.7)$ & & $31(11.5)$ & & \\
\hline APRI score & & & & & \\
\hline$<1.15$ & $58(39.2)$ & 148 & $140(47.5)$ & 295 & 0.099 \\
\hline$>1.15$ & $90(60.8)$ & & $155(52.5)$ & & \\
\hline mART score & & & & & \\
\hline$\leq 1.5$ & $42(60.0)$ & 70 & $93(65.5)$ & 142 & 0.434 \\
\hline$>2.5$ & $28(40.0)$ & & $49(34.5)$ & & \\
\hline ART score & & & & & \\
\hline$\leq 1.5$ & $22(57.9)$ & 38 & $29(61.7)$ & 47 & 0.722 \\
\hline$\geq 2.5$ & $16(42.1)$ & & $18(38.3)$ & & \\
\hline Okuda stage & & & & & \\
\hline I & $75(53.2)$ & 141 & $125(43.9)$ & 285 & 0.112 \\
\hline II & $62(44.0)$ & & $143(50.2)$ & & \\
\hline III & $4(2.8)$ & & $17(6.0)$ & & \\
\hline
\end{tabular}


Table 3 (continued)

\begin{tabular}{|c|c|c|c|c|c|}
\hline \multirow{2}{*}{$\begin{array}{l}\text { Distribution of scores at } \\
\text { TACE procedures }\end{array}$} & \multicolumn{2}{|c|}{ Bridging dataset } & \multicolumn{2}{|c|}{ Palliative dataset } & \multirow[t]{2}{*}{$p$} \\
\hline & $N(\%)$ & Total $(N)$ & $N(\%)$ & Total $(N)$ & \\
\hline \multicolumn{6}{|l|}{ MELD score } \\
\hline$<10$ & $73(49.3)$ & 148 & $190(64.0)$ & 297 & 0.003 \\
\hline$\geq 10$ & $75(50.7)$ & & $107(36.0)$ & & \\
\hline
\end{tabular}

palliative collective a significant number of patients received TACE in advanced disease stages (BCLC C), an ROC analysis was additionally performed exclusively for BCLC B stage $(n=182)$ but with comparable results (data not shown).

\section{Performance of scores in the bridging dataset}

\section{Median overall survival (OS)}

Only the BCLC score showed significance with regard to median OS in the bridging group $(p=0.002)$ but without decreasing survival time from stage A to stage D (Table 4; Fig. 3).

\section{Treatment discontinuation}

The bridging dataset does not include TACE sessions of patients who had to stop the general TACE therapy because of adverse events or death (Table 2). Therefore the ROC analysis concerning treatment discontinuation was only calculated in the palliative dataset (Table 6).

Receiving an unsuccessful TACE (per patient) does not have influence in overall survival for the bridging $(p=0.803)$ but for the palliative cohort $(p=0.046)$.

\section{3-years survival}

In the bridging group the CLIP score reached the best AUC with a value of $60.0 \%$, but there was no significance in the ROC analysis. Furthermore, none of the other scores reached statistical significance concerning the probability of achieving 3-years survival.

\section{Discussion}

Treatment decisions in hepatocellular carcinoma are often complex. In the context of stage migration the assessment of prognostic factors in patients with $\mathrm{HCC}$ is crucial for clinical management. For TACE, prognostic scores should provide adequate therapeutic guidance and avoid over-treatment or inadequate response. The aim of this study was a comparative evaluation of the reported panel of scores predicting prognosis of patients undergoing TACE.
Besides the common application of these scores in palliative treatment, the study also evaluated the applicability of these scores for patients undergoing TACE as bridging to LT. Statistical analysis showed that the different scores are not equally applicable in both datasets:

In the palliative dataset most of the scores reached statistical significance for predicting OS, whereas in the bridging dataset, only the BCLC score showed significance. In contrast to the study of Hannover Medical School, in our analysis there was no equally applicable score for both datasets of median OS. However, a significant discriminator regarding prediction of OS between both groups was the number of successfully performed TACE procedures $(p=0.001$; Table 7) for the palliative cohort (but not in the bridging collective; $p=0.354$ ). This is in line with the substantial number of patients suffering from advanced liver disease and enlarged tumor size in the palliative subgroup.

There is a certain selection bias due to the calculation of different endpoints per TACE rather than per patient. Nevertheless our results of median overall in both datasets (independently of the subgroups of the different scores) are consistent with previous studies (Abbasi et al. 2017; Biolato et al. 2014; Groupe d'Etude et de Traitement du Carcinome Hepatocellulaire 1995; Llovet and Bruix 2003, 2008). In the palliative dataset most scores predict significant differences in median OS. Contrary to current recommendations (Hucke et al. 2014b; Sieghart et al. 2013; Yin et al. 2016), we cannot validate the prognostic power of the ART score neither concerning the endpoint OS nor other endpoints (3-years survival, therapy discontinuation).Various studies also showed that the ART score is not suitable to reflect the OS of patients undergoing TACE in palliative intention (Terzi et al. 2014; Tseng et al. 2015).

The SNACOR score also did not show any applicability concerning all endpoints in our analysis. It was developed in 2016 (Kim et al. 2016) and evaluated in one more study in 2018 (Mahringer-Kunz et al. 2018), in which it also failed to distinguish prognostic subgroups (Mahringer-Kunz et al. 2018). Even though there was no significance of the original score, a certain applicability of the modified version of the mentioned score concerning the endpoint median OS in the palliative dataset was shown. Apart from the ART, mART and SNACOR score, all other scores in the palliative subgroup revealed significant differences of median OS 
Table 4 Uni- and multivariate analysis of scores in bridging vs. palliative dataset

\begin{tabular}{|c|c|c|c|c|}
\hline Score & $\begin{array}{l}\text { Bridging dataset } \\
\text { Median OS, months (SD; 95\% CI) }\end{array}$ & $p(\mathrm{u} / \mathrm{m})$ & $\begin{array}{l}\text { Palliative dataset } \\
\text { Median OS, months (SD; 95\% CI) }\end{array}$ & $p(\mathrm{u} / \mathrm{m})$ \\
\hline \multicolumn{5}{|l|}{ CLIP group } \\
\hline 0 & Not reached & \multirow[t]{5}{*}{$0.335 /-$} & $37.4(3.1 ; 31.4-43.4)$ & \multirow[t]{5}{*}{$<0.001 / 0.605$} \\
\hline 1 & Not reached & & $38.0(7.4 ; 23.5-52.4)$ & \\
\hline 2 & Not reached & & $16.7(2.3 ; 12.1-21.3)$ & \\
\hline 3 & Not reached & & $12.6(1.9 ; 8.8-16.3)$ & \\
\hline 4 & Not reached & & $7.5(1.9 ; 3.7-11.3)$ & \\
\hline \multicolumn{5}{|l|}{ mART score } \\
\hline$<2.5$ & Not reached & \multirow[t]{2}{*}{$0.472 /-$} & $17.2(3.9 ; 9.6-24.8)$ & \multirow[t]{2}{*}{$0.069 /$} \\
\hline$\geq 2.5$ & Not reached & & $11.1(2.6 ; 5.9-16.3)$ & \\
\hline \multicolumn{5}{|l|}{ ART score } \\
\hline$<2.5$ & Not reached & \multirow[t]{2}{*}{$0.110 /-$} & $18.1(5.0 ; 8.4-27.8)$ & \multirow[t]{2}{*}{$0.882 /$} \\
\hline$\geq 2.5$ & $39.0^{\mathrm{b}}$ & & $33.1(14.5 ; 4.7-61.6)$ & \\
\hline \multicolumn{5}{|l|}{ ALBI group } \\
\hline A1 & Not reached & \multirow[t]{3}{*}{$0.360 /-$} & $30.1(3.4 ; 23.4-36.8)$ & \multirow[t]{3}{*}{$<0.001 / 0.372$} \\
\hline $\mathrm{A} 2$ & Not reached & & $16.9(2.3 ; 12.3-21.5)$ & \\
\hline A3 & Not reached & & $5.1(0.9 ; 3.3-6.8)$ & \\
\hline \multicolumn{5}{|l|}{ APRI score } \\
\hline$\leq 1.15$ & Not reached & \multirow[t]{2}{*}{$0.396 /-$} & $31.2(3.5 ; 24.4-38.0) 14.5(1.4 ; 11.8-17.2)$ & \multirow[t]{2}{*}{$<0.001 / 0.072$} \\
\hline$>1.15$ & Not reached & & $31.2(3.5 ; 24.4-38.0) 14.5(1.4 ; 11.8-17.2)$ & \\
\hline \multicolumn{5}{|c|}{ mSNACOR stage } \\
\hline Low risk & $51.8(12.3 ; 27.6-75.9)$ & \multirow[t]{3}{*}{$0.371 /-$} & $80.5^{\mathrm{b}}$ & \multirow[t]{3}{*}{$<0.001 / 0.006$} \\
\hline Interm. risk & Not reached & & $20.6(4.7 ; 11.5-29.8)$ & \\
\hline High risk & No cases & & $10.4(2.5 ; 5.4-15.3)$ & \\
\hline \multicolumn{5}{|c|}{ SNACOR stage } \\
\hline Low risk & $39.0(10.9 ; 17.6-60.4)$ & \multirow[t]{3}{*}{$0.380 /-$} & $32.8^{\mathrm{b}}$ & \multirow[t]{3}{*}{$0.253 /$} \\
\hline Interm. risk & $60.8^{\mathrm{b}}$ & & $28.0(9.9 ; 8.6-47.4)$ & \\
\hline High risk & No cases & & $17.2(8.6 ; 0.3-34.1)$ & \\
\hline \multicolumn{5}{|l|}{ HAP stage } \\
\hline A & Not reached & $0.687 /-$ & $35.2(3.6 ; 28.1-42.2)$ & $<0.001 / 0.924$ \\
\hline B & Not reached & & $26.6(4.8 ; 17.2-35.9)$ & \\
\hline $\mathrm{C}$ & Not reached & & $13.0(2.0 ; 8.9-17.0)$ & \\
\hline $\mathrm{D}$ & Not reached & & $11.1(1.8 ; 7.5-14.7)$ & \\
\hline STATE score & & & & \\
\hline$\geq 18$ & Not reached & $0.804 /-$ & $24.1(2.7 ; 18.8-29.3)$ & $<0.001 /<0.001$ \\
\hline$<18$ & $45.5(23.8 ; 0-92.2)$ & & $13.7(0.9 ; 12.1-15.4)$ & \\
\hline Child-Pugh c & & & & \\
\hline A & Not reached & $0.473 /-$ & $27.9(3.2 ; 21.7-34.1)$ & $<0.001 /<0.001$ \\
\hline B & Not reached & & $11.2(1.5 ; 8.2-14.1)$ & \\
\hline $\mathrm{C}$ & Not reached & & $4.2(0.5 ; 3.2-5.3)$ & \\
\hline BCLC stage & & & & \\
\hline A & Not reached & $0.002 /-$ & $32.8(4.4 ; 24.2-41.5)$ & $<0.001 / 0.218$ \\
\hline B & $45.5(12.4 ; 21.1-69.8)$ & & $21.6(2.5 ; 16.7-26.6)$ & \\
\hline $\mathrm{C}$ & Not reached & & $21.8(8.8 ; 4.6-39.1)$ & \\
\hline $\mathrm{D}$ & Not reached & & $4.2(0.5 ; 3.3-5.2)$ & \\
\hline Okuda stage & & & & \\
\hline I & Not reached & $0.330 /-$ & $36.3(3.1 ; 30.2-42.4)$ & $<0.001 / 0.065$ \\
\hline II & Not reached & & $14.7(1.0 ; 12.7-16.6)$ & \\
\hline III & Not reached & & $3.5(1.1 ; 1.3-5.6)$ & \\
\hline
\end{tabular}


Table 4 (continued)

\begin{tabular}{|c|c|c|c|c|}
\hline Score & $\begin{array}{l}\text { Bridging dataset } \\
\text { Median OS, months (SD; 95\% CI) }\end{array}$ & $p(\mathrm{u} / \mathrm{m})$ & $\begin{array}{l}\text { Palliative dataset } \\
\text { Median OS, months (SD; 95\% CI) }\end{array}$ & $p(\mathrm{u} / \mathrm{m})$ \\
\hline \multicolumn{5}{|c|}{ MELD } \\
\hline$<10$ & Not reached & $0.213 /-$ & $25.3(2.5 ; 20.4-30.1)$ & $0.001 / 0.167$ \\
\hline$\geq 10$ & $62.0(8.8 ; 44.8-79.1)$ & & $12.6(1.7 ; 9.2-15.9)$ & \\
\hline Total $^{\mathrm{a}}$ & Not reached & & $21.8(2.7 ; 16.6-27.1)$ & $<0.001$ \\
\hline
\end{tabular}

Kaplan-Meier and Cox Regression; $p(\mathrm{u} / \mathrm{m})=p$ (univariate analysis) $/ p$ (multivariate analysis); $S D$ standard deviation, $95 \%$ CI $95 \%$ confidence interval

${ }^{a}$ Excluded from multivariate analysis

${ }^{\mathrm{b}}$ Not enough cases

depending on their prognostic groups. These scores may stratify the prognosis of patients undergoing TACE as palliative therapy.

As a result of multivariate analysis only three scores could predict independently median OS of patients undergoing TACE in palliative intention: the mSNACOR, STATE and Child-Pugh score. The applicability of the Child-Pugh score for patients undergoing TACE therapy has been validated in several studies (Brown et al. 2004; Dhanasekaran et al. 2010; El Khaddari et al. 2002; Mondazzi et al. 1994), even though there are also studies indicating that Child-Pugh scoring system is highly subjective (Cholongitas et al. 2005; Durand and Valla 2008). According to our analysis we support the application of the Child-Pugh score for predicting the OS in patients undergoing palliative TACE. The most applicable score to predict the probability of a later TACE discontinuation was the Child score. This appears suitable to the fact of the several laboratory and clinical markers which count into Child score: albumin, INR, bilirubin, encephalopathy and ascites. Although the two last ones are highly subjective, the Child score seems to reflect liver synthesis in case of TACE therapy in palliative intention at its best. Severe impact of liver synthesis is one of the most important reasons of treatment discontinuation besides vascular infiltration.

Due to the missing significances of the ART score in our analysis, we do not support the recommendation of sequential using the STATE score and the ART score to assess the prognosis of patients undergoing TACE (Hucke et al. 2014a). We can support the application of the STATE score at each TACE session for the assessment of OS in patients undergoing palliative TACE treatments. The mSNACOR is also an independent predictor of OS in palliative setting. In general it should be calculated in comparison to the previous TACE instead to the first TACE. Furthermore, it should be calculated at each TACE procedure instead of only at the second TACE. The SNACOR score needs further evaluation (Mahringer-Kunz et al. 2018), due to the fact, that the SNACOR score, in contrast to the mSNACOR score, did not reach any statistical significance concerning the endpoint $\mathrm{OS}$ in the palliative dataset. The analysis showed a certain applicability of the Child-Pugh, Okuda, HAP and CLIP score for the assessment of the probability of achieving a 3-years survival after TACE procedure. Nevertheless, none of the scores reached an AUC of more than $70 \%$, which is why a further evaluation or modification of the scores is needed concerning the mentioned endpoint to support clinical decision making. All the mentioned four scores were validated in various studies, but mainly regarding to the endpoint of median OS (Allgaier et al. 1998; Dhanasekaran et al. 2010; Farinati et al. 2000; Georgiades et al. 2006; Kadalayil et al. 2013; op den Winkel et al. 2012; Pinato et al. 2016; Rabe et al. 2003). We recommend that scores should be evaluated concerning further endpoints additional to the endpoint of OS. The probability of discontinuation of TACE therapy due to $\mathrm{AE}$ or death is another important endpoint to decide which scores have a prognostic importance. The Child-Pugh score as well as the MELD score showed the best applicability concerning AE or death in our analysis.

The MELD score is an established score especially in patients awaiting LT (Bruns et al. 2014; Kamath et al. 2001), but it may also be useful for predicting certain AE or mortality in patients undergoing TACE procedures (Hinrichs et al. 2017; Sawhney et al. 2011; Testa et al. 2003). According to our analysis, further studies that examine the relation of MELD score before TACE procedure and the probability of discontinuation of TACE therapy would be desirable.

In the univariate analysis of the bridging dataset only the BCLC score was a statistically significant predictor of overall survival, but in contrast to the original publication of the BCLC score (Llovet et al. 1999a), there is no decreasing survival time from stage A (early stage) to stage D (terminal stage), which is shown impressively in Fig. 3. Child-Pugh class $\mathrm{C}$ is always accompanied by a BCLC stage $\mathrm{D}$ as well as a performance status (PST) stage 1 or 2 is always accompanied by a BCLC stage C. Assuming that a patient has a Child-Pugh class B with, e.g., 9 points at the first TACE, he can be upgraded to 10 points at the second TACE due to a single parameter change. Thus, the patient changes the 
Kaplan Meier curves in the palliative dataset: $p(u)=p($ univariate), $p(m)=p($ multivariate)
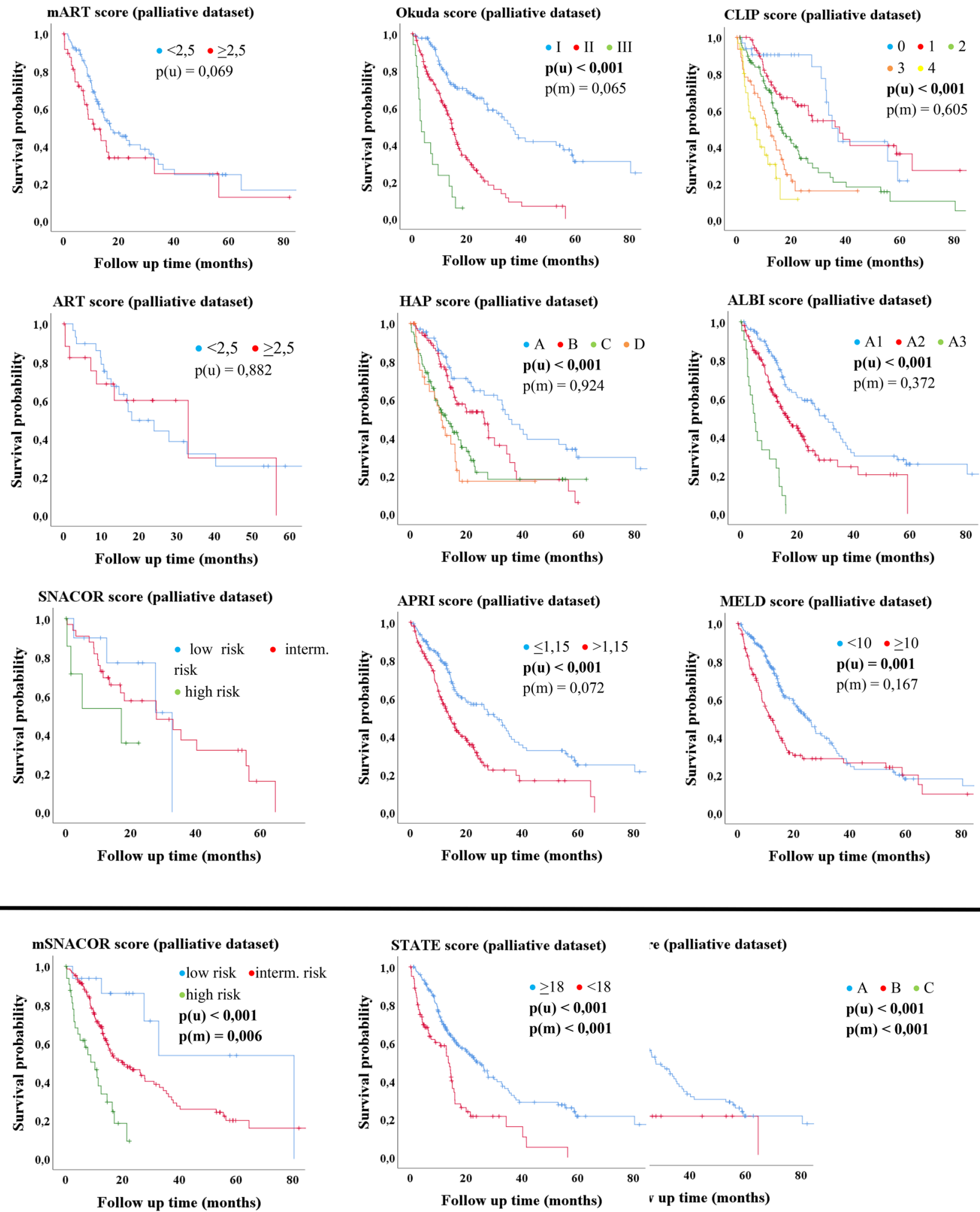

$-A \bullet B \cdot C$
$\mathbf{p}(\mathbf{u})<\mathbf{0 , 0 0 1}$
$\mathbf{p}(\mathbf{m})<\mathbf{0 , 0 0 1}$

Fig. 2 Kaplan-Meier-analysis: palliative dataset 
Fig. 3 Kaplan-Meier-analysis: BCLC score
BCLC score (bridging dataset)

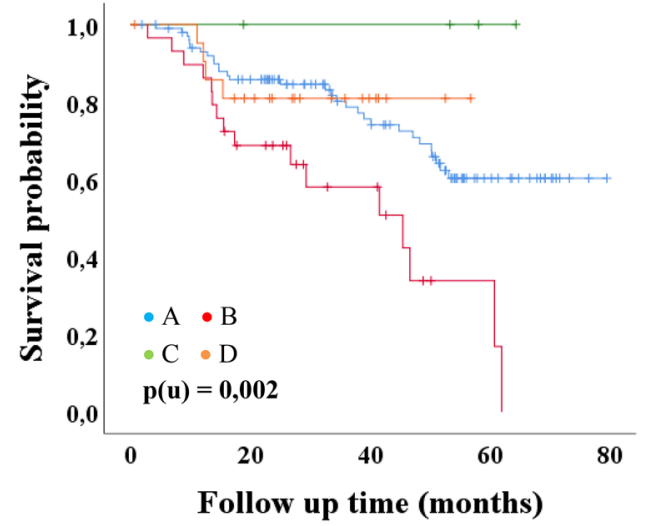

A Child-Pugh score (palliative dataset)

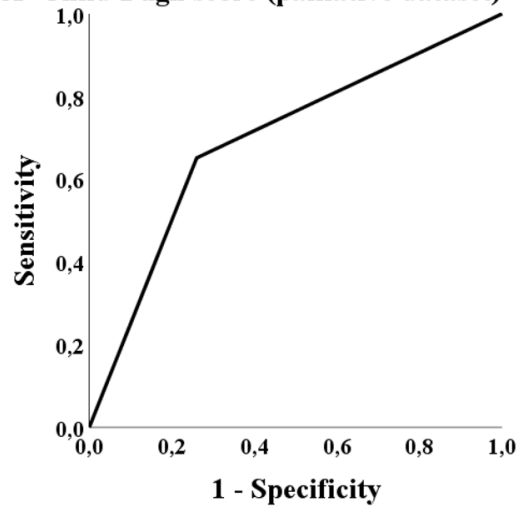

B MELD score (palliative dataset)

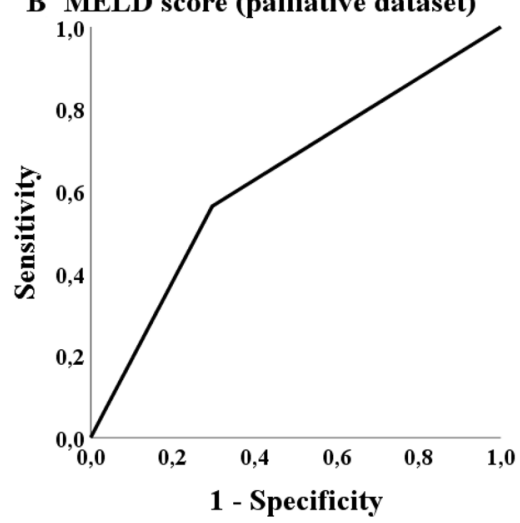

BCLC score (palliative dataset)

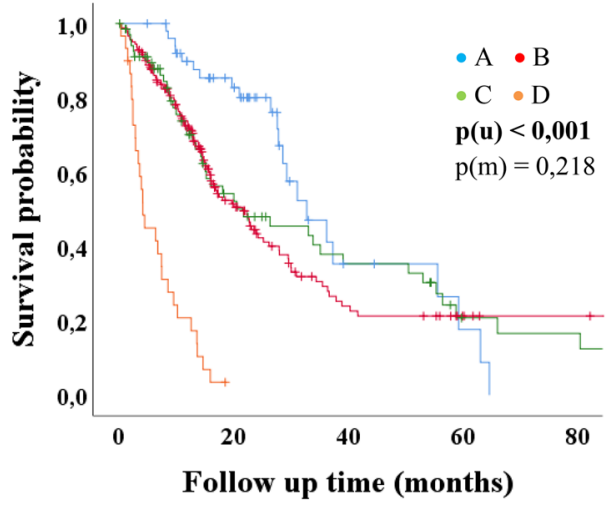

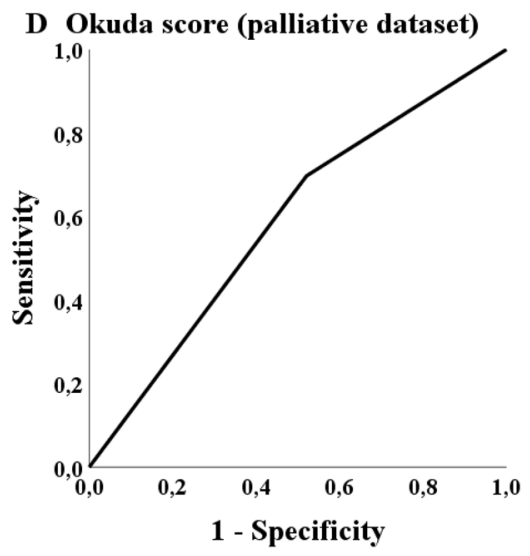
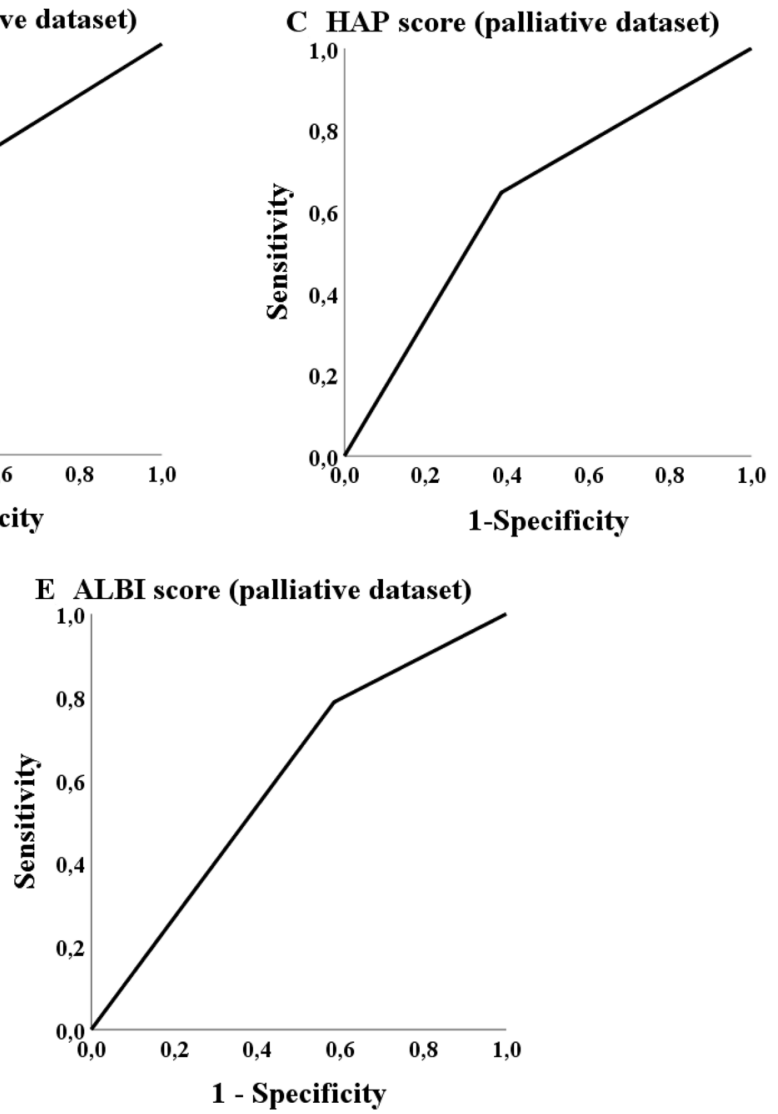

Fig. 4 ROC analysis: treatment discontinuation

Child-Pugh class from B to $\mathrm{C}$ and is therefore also associated with the BCLC stage D (Llovet et al. 1999a). Accordingly, a patient may also change from a BCLC stage A to a stage D, because a Child-Pugh class A or B does not limit the BCLC score to a specific stage, whereas a Child-Pugh class $\mathrm{C}$ is always associated with a BCLC D (Llovet et al. 1999a). However, the Child-Pugh score also includes subjective parameters (Cholongitas et al. 2005; Durand and
Valla 2008), why this definition (Child-Pugh C = BCLC D) should be critically scrutinized for patients receiving a TACE as bridging to LT therapy.

The BCLC score has been validated in several studies (Cillo et al. 2004; Llovet et al. 1999a; Marrero et al. 2005; Vitale et al. 2009; Zhao et al. 2015). The $p$ value in our univariate analysis of our palliative dataset also suggests that the BCLC score is suitable for assessing survival of 
Table 5 ROC Analysis concerning 3-years survival

\begin{tabular}{|c|c|c|c|c|}
\hline Score & $\begin{array}{l}\text { Bridging dataset } \\
\text { AUC (sensitivity/1 - speci- } \\
\text { ficity) }\end{array}$ & $p$ & $\begin{array}{l}\text { Palliative dataset } \\
\text { AUC (sensitivity/1-speci- } \\
\text { ficity) }\end{array}$ & $p$ \\
\hline CLIP group (0-1 vs. $2-4)$ & $0.600(0.567 / 0.367)$ & 0.095 & $0.646(0.754 / 0.462)$ & $<0.001$ \\
\hline mART score $(<2.5$ vs. $\geq 2.5)$ & $0.542(0.467 / 0.382)$ & 0.616 & $0.520(0.364 / 0.323)$ & 0.678 \\
\hline ART score $(<2.5$ vs. $\geq 2.5)$ & $0.588(0.566 / 0.379)$ & 0.430 & $0.423(0.304 / 0.458)$ & 0.366 \\
\hline ALBI group (A1 vs. $\mathrm{A} 2+\mathrm{A} 3)$ & $0.526(0.800 / 0.748)$ & 0.661 & $0.560(0.689 / 0.568)$ & 0.080 \\
\hline APRI score $(\leq 1.15$ vs. $>1.15)$ & $0.577(0.727 / 0.574)$ & 0.180 & $0.585(0.606 / 0.436)$ & 0.011 \\
\hline mSNACOR stage (low- and interm. risk vs. high risk) & - & - & $0.564(0.232 / 0.104)$ & 0.122 \\
\hline SNACOR stage (low- and interm. risk vs. high risk) & - & - & $0.503(0.160 / 0.154)$ & 0.970 \\
\hline mSNACOR stage (low risk vs. interm risk) & $0.484(0.737 / 0.768)$ & 0.835 & - & - \\
\hline SNACOR stage (low risk vs. interm risk) & $0.455(0.667 / 0.758)$ & 0.679 & - & - \\
\hline HAP stage $(A+B$ vs. $C+D)$ & $0.552(0.600 / 0.495)$ & 0.381 & $0.607(0.549 / 0.336)$ & 0.002 \\
\hline State score $(\geq 18$ vs. $<18)$ & $0.476(0.033 / 0.081)$ & 0.689 & $0.553(0.340 / 0.235)$ & 0.128 \\
\hline Child-Pugh class (A vs. B +C) & $0.557(0.600 / 0.486)$ & 0.341 & $0.648(0.490 / 0.194)$ & $<0.001$ \\
\hline BCLC stage $(\mathrm{A}+\mathrm{B}$ vs. $\mathrm{C}+\mathrm{D})$ & $0.470(0.118 / 0.177)$ & 0.594 & $0.559(0.357 / 0.239)$ & 0.063 \\
\hline Okuda stage (A vs. B + C) & $0.541(0.533 / 0.487)$ & 0.487 & $0.657(0.709 / 0.396)$ & $<0.001$ \\
\hline MELD score $(<10$ vs. $\geq 10)$ & $0.544(0.576 / 0.487)$ & 0.438 & $0.573(0.429 / 0.284)$ & 0.030 \\
\hline
\end{tabular}

$A U C$ area under the receiver operating characteristic curve
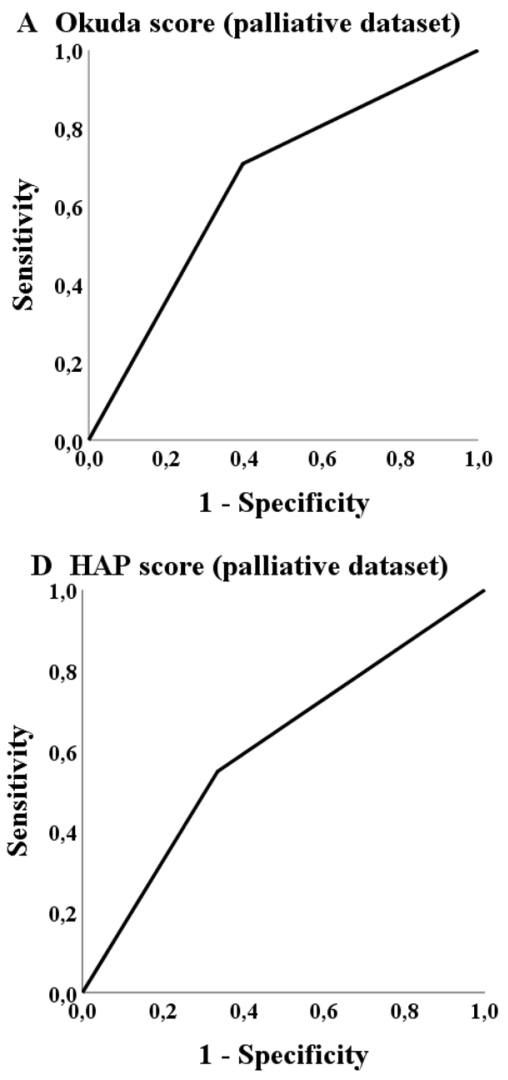

Fig. 5 ROC analysis: 3-years survival
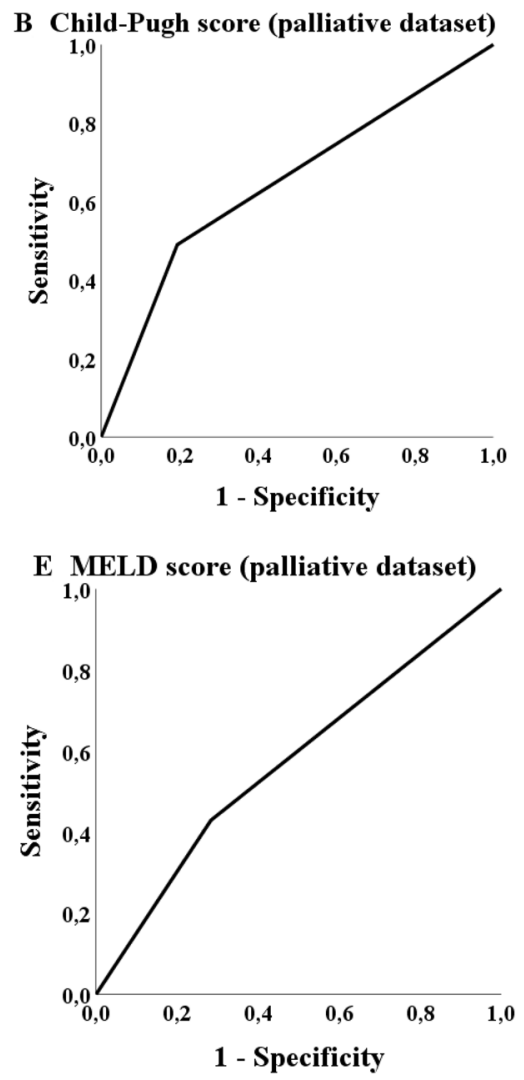
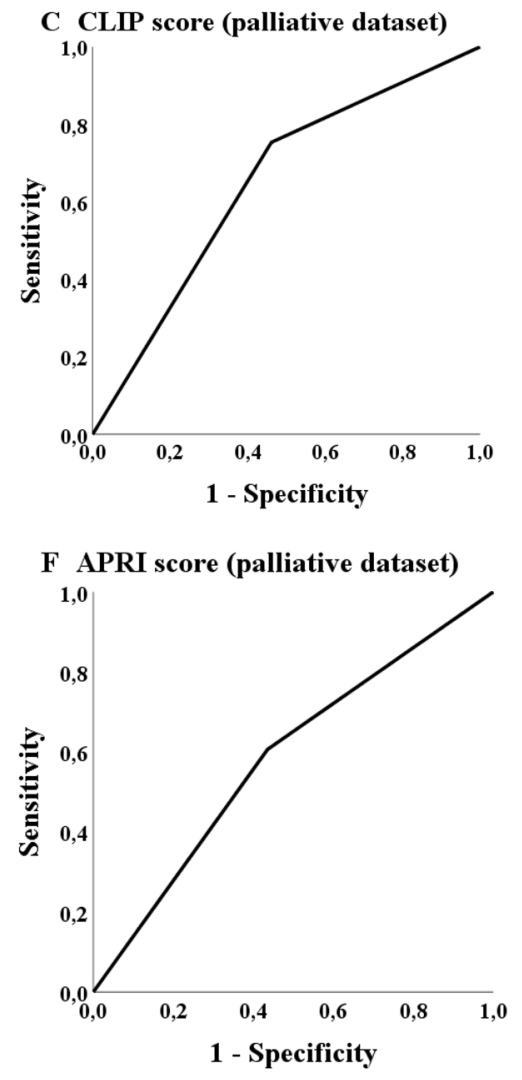
Table 6 ROC analysis concerning therapy discontinuation

\begin{tabular}{llr}
\hline Score & $\begin{array}{l}\text { Palliative dataset } \\
\text { AUC (sensitivity/1 - specific- }\end{array}$ \\
& \multicolumn{1}{l}{$\begin{array}{l}\text { ity) } \\
\text { CLIP group (0-1 vs. 2-4) }\end{array}$} & 0.113 \\
mART score (<2.5 vs. $\geq 2.5)$ & $0.565(0.712 / 0.583)$ & 0.084 \\
ART score (<2.5 vs. $\geq 2.5)$ & $0.596(0.486 / 0.295)$ & 0.533 \\
ALBI group (A1 vs. A2+A3) & $0.571(0.500 / 0.359)$ & 0.013 \\
APRI score ( $\leq 1.15$ vs. $>1.15)$ & $0.601(0.788 / 0.585)$ & 0.217 \\
mSNACOR stage (low- and interm. risk vs. high risk) & $0.549(0.600 / 0.502)$ & 0.091 \\
SNACOR stage (low- and interm. risk vs. high risk) & $0.581(0.292 / 0.129)$ & 0.184 \\
HAP stage (A+B vs. C+D) & $0.632(0.364 / 0.100)$ & 0.002 \\
STATE score ( $\geq 18$ vs. $<18)$ & $0.630(0.646 / 0.385)$ & 0.242 \\
Child-Pugh class (A vs. B +C) & $0.548(0.364 / 0.269)$ & $<0.001$ \\
BCLC stage (A+B vs. C+D) & $0.696(0.652 / 0.260)$ & 0.343 \\
Okuda stage (A vs. B +C) & $0.536(0.356 / 0.284)$ & 0.030 \\
MELD score (<10 vs. $\geq 10)$ & $0.588(0.697 / 0.521)$ & 0.001 \\
\hline
\end{tabular}

$A U C$ area under the receiver operating characteristic curve

Table 7 Kaplan-Meier-analysis: number of successful TACE procedures

\begin{tabular}{llll}
\hline $\begin{array}{l}\text { Applicability of further parameters concerning the } \\
\text { prediction of OS (Kaplan-Meier analysis) }\end{array}$ & $\begin{array}{l}\text { Bridging dataset } \\
n=61 \\
\text { Median OS (months) (SD; } \\
95 \% \text { CI) }\end{array}$ & $p(\mathrm{u})$ & $\begin{array}{l}\text { Palliative dataset } \\
n=87 \\
\text { Median OS (months) (SD; } \\
95 \% \text { CI) }\end{array}$ \\
\hline$<2$ & Not reached & 0.354 & $6.0(8.4 ; 0.0-22.4)$ \\
$2-4$ & 62.0 & & $16.0(1.1 ; 13.8-18.2)$ \\
$>4$ & $51.1(16.4 ; 19.0-83.2)$ & $41.7(13.7 ; 14.8-68.6)$ \\
\hline
\end{tabular}

patients with TACE treatment. We do not agree with various studies that suggest that the BCLC score is generally suitable for assessing the overall survival of all patients, without making any declaration about therapy indication (Dhanasekaran et al. 2010; Zhang et al. 2014). We do not support the statement that a BCLC stage D is associated with the worst prognosis concerning OS among our analysis, regardless of whether the TACE is performed as bridging to LT or in a palliative intention.

ROC Analysis in the palliative collective reveals similar results for patients with BCLC B in comparison to all other BCLC scores with endpoint treatment discontinuation or 3 years OS (data not shown). Therefore, we conclude that the scores are independent in performance concerning BCLC stadium. Scores do not perform better, if only BLCLC stage B patients are analyzed.

But substantial differences in the performance of the various scores were evident when comparing AUROC in dependence of etiology of liver disease. For the three most frequent etiologies in our cohort (viral, alcoholic and cryptogenic/NASH in descending order) ROC analysis for the endpoints "3 years survival" and "treatment discontinuation" were remarkable different, revealing etiology as a potential confounding factor (Tables 8, 9). Overall performance of the Scoring systems seems to be best for viral etiologies, but poor in alcoholic liver disease patients.

In general, the ROC analysis for both groups revealed that there is no score reflecting a sufficiently selectivity to make clear clinical decisions. This is probably influenced by the fact that a TACE procedure is still not sufficiently standardized. Neither concerning the type of intervention (conventional, DEB, biodegradable), nor the frequency of the TACE procedures or regarding to the different subsequent therapies (RFA, Sorafenib, BSC etc.) are currently standardized selection criteria. According to the results of the bridging dataset further evaluations and modifications of scores are needed, especially for patients receiving TACE procedures as bridging to LT therapy. 
Table 8 ROC analysis: treatment discontinuation comparing different etiologies

\begin{tabular}{|c|c|c|c|c|c|c|}
\hline \multirow[t]{2}{*}{ ROC-analysis concerning 3-years survival } & \multicolumn{2}{|c|}{$\begin{array}{l}\text { Palliative dataset } \\
\text { Viral subgroup } \\
N=120(35.9 \%)\end{array}$} & \multicolumn{2}{|c|}{$\begin{array}{l}\text { Palliative } \\
\text { dataset } \\
\text { Alcoholic } \\
\text { subgroup } \\
N=96(28.7 \%)\end{array}$} & \multicolumn{2}{|c|}{$\begin{array}{l}\text { Palliative } \\
\text { dataset } \\
\text { Cryptogenic/ } \\
\text { NASH sub- } \\
\text { group } \\
N=59(17.7 \%)\end{array}$} \\
\hline & AUC & $p$ & AUC & $p$ & AUC & $p$ \\
\hline CLIP group (0-1 vs. $2-4)$ & 0.729 & $<0.001$ & 0.504 & 0.953 & 0.576 & 0.382 \\
\hline mART score $(<2.5$ vs. $\geq 2.5)$ & 0.589 & 0.303 & 0.591 & 0.302 & 0.417 & 0.497 \\
\hline ART score $(<2.5$ vs. $\geq 2.5)$ & 0.500 & 1.000 & 0.500 & 1.000 & 0.643 & 0.663 \\
\hline ALBI group (A1 vs. A2+A3) & 0.617 & 0.043 & 0.463 & 0.549 & 0.654 & 0.064 \\
\hline APRI score ( $\leq 1.15$ vs. $>1.15)$ & 0.584 & 0.136 & 0.552 & 0.400 & 0.542 & 0.610 \\
\hline mSNACOR stage (low- and interm. risk vs. high risk) & 0.661 & 0.021 & 0.545 & 0.547 & 0.569 & 0.759 \\
\hline SNACOR stage (low- and interm. risk vs. high risk) & 0.479 & 0.877 & 0.543 & 0.770 & 0.417 & 0.739 \\
\hline HAP stage $(\mathrm{A}+\mathrm{B}$ vs. $\mathrm{C}+\mathrm{D})$ & 0.707 & $<0.001$ & 0.503 & 0.968 & 0.693 & 0.027 \\
\hline STATE score ( $\geq 18$ vs. $<18$ ) & 0.564 & 0.271 & 0.656 & 0.012 & 0.481 & 0.821 \\
\hline Child-Pugh class (A vs. $\mathrm{B}+\mathrm{C}$ ) & 0.712 & $<0.001$ & 0.602 & 0.098 & 0.674 & 0.034 \\
\hline Okuda stage (A vs. B + C) & 0.766 & $<0.001$ & 0.552 & 0.396 & 0.551 & 0.533 \\
\hline $\operatorname{MELD}$ score $(<10$ vs. $\geq 10)$ & 0.693 & 0.001 & 0.507 & 0.915 & 0.524 & 0.769 \\
\hline BCLC score $(A+B$ vs. $C+D$ & 0.614 & 0.032 & 0.591 & 0.126 & 0.395 & 0.169 \\
\hline
\end{tabular}

Table 9 ROC analysis: 3-years survival comparing different etiologies

\begin{tabular}{|c|c|c|c|c|c|c|}
\hline \multirow[t]{2}{*}{ ROC-analysis concerning therapy discontinuation } & \multicolumn{2}{|c|}{$\begin{array}{l}\text { Palliative dataset } \\
\text { Viral subgroup } \\
N=120(35.9 \%)\end{array}$} & \multicolumn{2}{|c|}{$\begin{array}{l}\text { Palliative } \\
\text { dataset } \\
\text { Alcoholic } \\
\text { subgroup } \\
N=96(28.7 \%)\end{array}$} & \multicolumn{2}{|c|}{$\begin{array}{l}\text { Palliative } \\
\text { dataset } \\
\text { Cryptogenic/ } \\
\text { NASH sub- } \\
\text { group } \\
N=59(17.7 \%)\end{array}$} \\
\hline & AUC & $p$ & AUC & $p$ & AUC & $p$ \\
\hline CLIP group (0-1 vs. $2-4)$ & 0.710 & 0.002 & 0.503 & 0.968 & 0.750 & 0.037 \\
\hline mART score $(<2.5$ vs. $\geq 2.5)$ & 0.600 & 0.251 & 0.624 & 0.240 & 0.685 & 0.251 \\
\hline ART score $(<2.5$ vs. $\geq 2.5)$ & 0.546 & 0.767 & 0.596 & 0.671 & 0.643 & 0.663 \\
\hline ALBI group (A1 vs. A2+A3) & 0.655 & 0.019 & 0.550 & 0.474 & 0.762 & 0.028 \\
\hline APRI score ( $\leq 1.15$ vs. $>1.15)$ & 0.601 & 0.093 & 0.533 & 0.635 & 0.615 & 0.331 \\
\hline mSNACOR stage (low- and interm. risk vs. high risk) & 0.688 & 0.016 & 0.456 & 0.594 & 0.625 & 0.424 \\
\hline SNACOR stage (low- and interm. risk vs. high risk) & 0.567 & 0.663 & 0.617 & 0.461 & 1.000 & 0.127 \\
\hline HAP stage $(A+B$ vs. $C+D)$ & 0.691 & 0.005 & 0.504 & 0.953 & 0.895 & 0.001 \\
\hline STATE score ( $\geq 18$ vs. $<18$ ) & 0.587 & 0.187 & 0.486 & 0.842 & 0.709 & 0.077 \\
\hline Child-Pugh class (A vs. $\mathrm{B}+\mathrm{C}$ ) & 0.746 & $<0.001$ & 0.643 & 0.039 & 0.838 & 0.004 \\
\hline Okuda stage (A vs. B + C) & 0.795 & $<0.001$ & 0.453 & 0.500 & 0.690 & 0.109 \\
\hline MELD score (<10 vs. $\geq 10)$ & 0.670 & 0.008 & 0.517 & 0.805 & 0.817 & 0.007 \\
\hline BCLC score $(A+B$ vs. $C+D$ & 0.552 & 0.398 & 0.504 & 0.953 & 0.532 & 0.787 \\
\hline
\end{tabular}

\section{Conclusion}

The characteristics as well as the outcome of patients receiving TACE are significantly different depending on the therapy indication. In contrast to previous evaluations, scoring for OS after TACE should be separately evaluated for curative (LT) and palliative settings. Regarding TACE as palliative therapy the Child-Pugh score, STATE score and mSNACOR score performed best for the prediction of median OS. In contrast to other studies we could not validate a prognostic power of the ART score. Furthermore, the SNACOR score was only informative, when directly comparing serial, respectively, when it is calculated such as the mSNACOR.

Overall, none of the evaluated scores seems to be promising in terms of clinical decisions making with respect to stage migration in both cohorts. Only the BCLC score was able to predict the OS probability in the bridging dataset 
but without decreasing survival time from stage A to stage D. We conclude that further efforts are needed, especially in patients undergoing TACE as bridging to LT, to establish appropriate criteria for making valid predictions and thus support decision making processes in daily clinical routine.

Acknowledgements Open Access funding provided by Projekt DEAL. We thank Ms. Jessica Langel (Department of Gastroenterology, University Hospital Heidelberg) for administrative support.

Author contributions MV and IM contributed equally as an author. MM functions as corresponding author. JP, SDS, MK, AT, D-HC, CS, TL, UM, AM and KHW contributed as coauthors in the ranking mentioned above.

Funding There was no financial support or funding for the study.

\section{Compliance with ethical standards}

Conflict of interest All authors declare that there is no conflict of interest.

Statement of ethics All procedures performed in studies involving human participants were in accordance with the ethical standards of the institutional and/or national research committee and with the 1964 Helsinki declaration and its later amendments or comparable ethical standards.

Open Access This article is licensed under a Creative Commons Attribution 4.0 International License, which permits use, sharing, adaptation, distribution and reproduction in any medium or format, as long as you give appropriate credit to the original author(s) and the source, provide a link to the Creative Commons licence, and indicate if changes were made. The images or other third party material in this article are included in the article's Creative Commons licence, unless indicated otherwise in a credit line to the material. If material is not included in the article's Creative Commons licence and your intended use is not permitted by statutory regulation or exceeds the permitted use, you will need to obtain permission directly from the copyright holder. To view a copy of this licence, visit http://creativecommons.org/licenses/by/4.0/.

\section{References}

Abbasi AH, Abid S, Haq TU, Awan S (2017) Role of assessment for retreatment with transarterial chemoembolization score in decision of retreatment with trans-arterial chemo-embolization Sessions in patients with hepatocellular carcinoma. J Ayub Med Coll Abbottabad 29:378-383

Allgaier HP, Deibert P, Olschewski M, Spamer C, Blum U, Gerok W, Blum HE (1998) Survival benefit of patients with inoperable hepatocellular carcinoma treated by a combination of transarterial chemoembolization and percutaneous ethanol injection-a singlecenter analysis including 132 patients. Int J Cancer 79:601-605

Arii S et al (2000) Results of surgical and nonsurgical treatment for small-sized hepatocellular carcinomas: a retrospective and nationwide survey in Japan. Liver Cancer Study Group Jpn Hepatol 32:1224-1229. https://doi.org/10.1053/jhep.2000.20456

Biolato $\mathrm{M}$ et al (2014) Hepatocellular carcinoma treated by conventional transarterial chemoembolization in field-practice: serum sodium predicts survival. World J Gastroenterol 20:8158-8165. https://doi.org/10.3748/wjg.v20.i25.8158

Brown DB, Fundakowski CE, Lisker-Melman M, Crippin JS, Pilgram TK, Chapman W, Darcy MD (2004) Comparison of MELD and Child-Pugh scores to predict survival after chemoembolization for hepatocellular carcinoma. J Vasc Interv Radiol 15:1209-1218. https://doi.org/10.1097/01.rvi.0000128123.04554.c1

Bruix J, Sherman M (2005) Management of hepatocellular carcinoma. Hepatology 42:1208-1236. https://doi.org/10.1002/hep.20933

Bruix J, Sherman M, American Association for the Study of Liver D (2011) Management of hepatocellular carcinoma: an update. Hepatology 53:1020-1022. https://doi.org/10.1002/hep.24199

Bruns H, Lozanovski VJ, Schultze D, Hillebrand N, Hinz U, Buchler MW, Schemmer P (2014) Prediction of postoperative mortality in liver transplantation in the era of MELD-based liver allocation: a multivariate analysis. PLoS ONE 9:e98782. https://doi. org/10.1371/journal.pone.0098782

Cabibbo G, Enea M, Attanasio M, Bruix J, Craxi A, Camma C (2010) A meta-analysis of survival rates of untreated patients in randomized clinical trials of hepatocellular carcinoma. Hepatology 51:1274-1283. https://doi.org/10.1002/hep.23485

Child CG, Turcotte JG (1964) Surgery and portal hypertension. Major Probl Clin Surg 1:1-85

Cholongitas E, Papatheodoridis GV, Vangeli M, Terreni N, Patch D, Burroughs AK (2005) Systematic review: the model for end-stage liver disease-should it replace Child-Pugh's classification for assessing prognosis in cirrhosis? Aliment Pharmacol Ther 22:1079-1089. https://doi.org/10.111 $1 / \mathrm{j} .1365-2036.2005 .02691 . \mathrm{x}$

Cillo U et al (2004) The critical issue of hepatocellular carcinoma prognostic classification: which is the best tool available? J Hepatol 40:124-131

Cillo U et al (2006) Prospective validation of the Barcelona Clinic Liver Cancer staging system. J Hepatol 44:723-731. https://doi. org/10.1016/j.jhep.2005.12.015

Groupe d'Etude et de Traitement du Carcinome Hepatocellulaire (1995) A comparison of lipiodol chemoembolization and conservative treatment for unresectable hepatocellular carcinoma. $\mathrm{N}$ Engl J Med 332:1256-1261. https://doi.org/10.1056/nejm199505 113321903

Decaens $\mathrm{T}$ et al (2005) Impact of pretransplantation transarterial chemoembolization on survival and recurrence after liver transplantation for hepatocellular carcinoma. Liver Transpl 11:767-775. https://doi.org/10.1002/lt.20418

Dhanasekaran R, Kooby DA, Staley CA, Kauh JS, Khanna V, Kim HS (2010) Prognostic factors for survival in patients with unresectable hepatocellular carcinoma undergoing chemoembolization with doxorubicin drug-eluting beads: a preliminary study. HPB (Oxford) 12:174-180. https://doi.org/10.111 1/j.1477-2574.2009.00138.x

Durand F, Valla D (2008) Assessment of prognosis of cirrhosis. Semin Liver Dis 28:110-122. https://doi.org/10.1055/s-2008-1040325

El Khaddari S, Gaudin JL, Abidi H, Picaud G, Rode A, Souquet JC (2002) Chemoembolization in hepatocellular carcinoma: multivariate analysis of survival prognostic factors after the first session. Gastroenterol Clin Biol 26:728-734

Farinati F, Rinaldi M, Gianni S, Naccarato R (2000) How should patients with hepatocellular carcinoma be staged? Validation of a new prognostic system. Cancer 89:2266-2273

Georgiades CS, Liapi E, Frangakis C, Park JU, Kim HW, Hong K, Geschwind JF (2006) Prognostic accuracy of 12 liver staging systems in patients with unresectable hepatocellular carcinoma treated with transarterial chemoembolization. J Vasc Interv Radiol 17:1619-1624. https://doi.org/10.1097/01.rvi.0000236608.91960 .34 
Guglielmi A, Ruzzenente A, Pachera S, Valdegamberi A, Sandri M, D’Onofrio M, Iacono C (2008) Comparison of seven staging systems in cirrhotic patients with hepatocellular carcinoma in a cohort of patients who underwent radiofrequency ablation with complete response. Am J Gastroenterol 103:597-604. https://doi. org/10.1111/j.1572-0241.2007.01604.x

Hinrichs JB et al (2017) Health-related quality of life in patients with hepatocellular carcinoma treated with initial transarterial chemoembolization. Cardiovase Intervent Radiol 40:1559-1566. https ://doi.org/10.1007/s00270-017-1681-6

Ho SY et al (2017) Prognostic role of noninvasive liver reserve markers in patients with hepatocellular carcinoma undergoing transarterial chemoembolization. PLoS ONE 12:e0180408. https://doi. org/10.1371/journal.pone. 0180408

Hucke F et al (2014a) How to STATE suitability and START transarterial chemoembolization in patients with intermediate stage hepatocellular carcinoma. J Hepatol 61:1287-1296. https://doi. org/10.1016/j.jhep.2014.07.002

Hucke F et al (2014b) The ART-strategy: sequential assessment of the ART score predicts outcome of patients with hepatocellular carcinoma re-treated with TACE. J Hepatol 60:118-126. https:// doi.org/10.1016/j.jhep.2013.08.022

Ikai I et al (2004) Reevaluation of prognostic factors for survival after liver resection in patients with hepatocellular carcinoma in a Japanese Nationwide Survey. Cancer 101:796-802. https://doi. org/10.1002/cncr.20426

Johnson PJ et al (2015) Assessment of liver function in patients with hepatocellular carcinoma: a new evidence-based approach-the ALBI grade. J Clin Oncol 33:550-558. https://doi.org/10.1200/ jco.2014.57.9151

Kadalayil L et al (2013) A simple prognostic scoring system for patients receiving transarterial embolisation for hepatocellular cancer. Ann Oncol 24:2565-2570. https://doi.org/10.1093/annon c/mdt247

Kamath PS et al (2001) A model to predict survival in patients with end-stage liver disease. Hepatology 33:464-470. https://doi. org/10.1053/jhep.2001.22172

Kim BK et al (2016) Risk prediction for patients with hepatocellular carcinoma undergoing chemoembolization: development of a prediction model. Liver Int 36:92-99. https://doi.org/10.1111/ liv. 12865

Kollmann D, Selzner N, Selzner M (2017) Bridging to liver transplantation in HCC patients. Langenbecks Arch Surg 402:863-871. https://doi.org/10.1007/s00423-017-1609-2

Lee IC et al (2012) Transarterial chemoembolization can prolong survival for patients with metastatic hepatocellular carcinoma: a propensity score matching analysis. Hepatol Int 6:753-762. https ://doi.org/10.1007/s12072-011-9322-7

Li L, Gou CY, Li JY, Achakzai R, Li XH (2016) Cancer of the Liver Italian Program score helps identify potential candidates for transarterial chemoembolization in patients with Barcelona Clinic Liver Cancer stage C. Hepatobiliary Pancreat Dis Int 15:152-157

Llovet JM, Bru C, Bruix J (1999) Prognosis of hepatocellular carcinoma: the BCLC staging classification. Semin Liver Dis 19:329338. https://doi.org/10.1055/s-2007-1007122

Llovet JM, Bruix J (2003) Systematic review of randomized trials for unresectable hepatocellular carcinoma: chemoembolization improves survival. Hepatology 37:429-442. https://doi. org/10.1053/jhep.2003.50047

Llovet JM, Bruix J (2008) Novel advancements in the management of hepatocellular carcinoma. J Hepatol 48(Suppl 1):S20-37. https:// doi.org/10.1016/j.jhep.2008.01.022

Llovet JM et al (1999) Natural history of untreated nonsurgical hepatocellular carcinoma: rationale for the design and evaluation of therapeutic trials. Hepatology 29:62-67. https://doi.org/10.1002/ hep. 510290145

Llovet JM et al (2008) Design and endpoints of clinical trials in hepatocellular carcinoma. J Natl Cancer Inst 100:698-711. https://doi. org/10.1093/jnci/djn134

Llovet JM, Schwartz M, Mazzaferro V (2005) Resection and liver transplantation for hepatocellular carcinoma. Semin Liver Dis 25:181-200. https://doi.org/10.1055/s-2005-871198

Llovet JM, Ducreux M, Lencioni R, Di Bisceglie AM, Galle PR, Dufour JF, Greten TF, Raymond E, Roskams T, De Baere T, Mazzaferro V (2012) EASL-EORTC clinical practice guidelines: management of hepatocellular carcinoma. J Hepatol 56:908-943. https://doi.org/10.1016/j.jhep.2011.12.001

Mahringer-Kunz A et al (2018) Validation of the SNACOR clinical scoring system after transarterial chemoembolisation in patients with hepatocellular carcinoma. BMC Cancer 18:489. https://doi. org/10.1186/s12885-018-4407-5

Majno PE et al (1997) Influence of preoperative transarterial lipiodol chemoembolization on resection and transplantation for hepatocellular carcinoma in patients with cirrhosis. Ann Surg 226:688701 (discussion 701-683)

Marrero JA, Fontana RJ, Barrat A, Askari F, Conjeevaram HS, Su GL, Lok AS (2005) Prognosis of hepatocellular carcinoma: comparison of 7 staging systems in an American Cohort. Hepatology 41:707-716. https://doi.org/10.1002/hep.20636

Mondazzi L et al (1994) Transarterial oily chemoembolization for the treatment of hepatocellular carcinoma: a multivariate analysis of prognostic factors. Hepatology 19:1115-1123

Cancer of the Liver Italian Program (CLIP) Investigators (1998) A new prognostic system for hepatocellular carcinoma: a retrospective study of 435 patients: the Cancer of the Liver Italian Program (CLIP) investigators. Hepatology 28:751-755. https://doi. org/10.1002/hep.510280322

Okuda K et al (1985) Natural history of hepatocellular carcinoma and prognosis in relation to treatment. Study of 850 patients. Cancer 56:918-928

op den Winkel M et al (2012) Prognosis of patients with hepatocellular carcinoma. Validation and ranking of established staging-systems in a large western HCC-cohort. PLoS ONE 7:e45066. https://doi. org/10.1371/journal.pone.0045066

Pinato DJ et al (2016) Combined sequential use of HAP and ART scores to predict survival outcome and treatment failure following chemoembolization in hepatocellular carcinoma: a multicenter comparative study. Oncotarget 7:44705-44718. https:// doi.org/10.18632/oncotarget.9604

Porrett PM et al (2006) Lack of benefit of pre-transplant locoregional hepatic therapy for hepatocellular cancer in the current MELD era. Liver Transpl 12:665-673. https://doi.org/10.1002/lt.20636

Pugh RN, Murray-Lyon IM, Dawson JL, Pietroni MC, Williams R (1973) Transection of the oesophagus for bleeding oesophageal varices. Br J Surg 60:646-649

Rabe C, Lenz M, Schmitz V, Pilz T, Fimmers R, Sauerbruch T, Caselmann WH (2003) An independent evaluation of modern prognostic scores in a central European cohort of 120 patients with hepatocellular carcinoma. Eur J Gastroenterol Hepatol 15:1305-1315. https://doi.org/10.1097/01.meg.0000085503 .01212 .39

Sawhney S, Montano-Loza AJ, Salat P, McCarthy M, Kneteman N, Meza-Junco J, Owen R (2011) Transarterial chemoembolization in patients with hepatocellular carcinoma: predictors of survival. Can J Gastroenterol 25:426-432

Sieghart W et al (2013) The ART of decision making: retreatment with transarterial chemoembolization in patients with hepatocellular carcinoma. Hepatology 57:2261-2273. https://doi.org/10.1002/ hep. 26256 
Song YP, Zhao QY, Li S, Wang H, Wu PH (2016) Non-invasive fibrosis indexes in predicting acute liver function deterioration after transcatheter arterial chemoembolization. Zhonghua Yi Xue Za Zhi 96:716-719. https://doi.org/10.3760/cma.j.i ssn.0376-2491.2016.09.011

Takayasu K et al (2006) Prospective cohort study of transarterial chemoembolization for unresectable hepatocellular carcinoma in 8510 patients. Gastroenterology 131:461-469. https://doi.org/10.1053/j. gastro.2006.05.021

Terzi E et al (2014) The ART score is not effective to select patients for transarterial chemoembolization retreatment in an Italian series. Dig Dis 32:711-716. https://doi.org/10.1159/000368007

Testa R et al (2003) Trans-catheter arterial chemoembolisation for hepatocellular carcinoma in patients with viral cirrhosis: role of combined staging systems, Cancer Liver Italian Program (CLIP) and Model for End-stage Liver Disease (MELD), in predicting outcome after treatment. Aliment Pharmacol Ther 17:1563-1569

Tseng CL et al (2015) The effectiveness of ART score in selecting patients for transarterial chemoembolization retreatment: a cohort study in Taiwan. Medicine (Baltimore) 94:e1659. https://doi. org/10.1097/md.0000000000001659

Vitale A et al (2009) Validation of the BCLC prognostic system in surgical hepatocellular cancer patients. Transplant Proc 41:12601263. https://doi.org/10.1016/j.transproceed.2009.03.054
Wai CT, Greenson JK, Fontana RJ, Kalbfleisch JD, Marrero JA, Conjeevaram HS, Lok AS (2003) A simple noninvasive index can predict both significant fibrosis and cirrhosis in patients with chronic hepatitis C. Hepatology 38:518-526. https://doi.org/10.1053/ jhep.2003.50346

Yin W et al (2016) ART score and hepatocellular carcinoma: An appraisal of its applicability. Clin Res Hepatol Gastroenterol 40:705-714. https://doi.org/10.1016/j.clinre.2016.05.005

Zhang JF et al (2014) Prognosis of unresectable hepatocellular carcinoma: comparison of seven staging systems (TNM, Okuda, BCLC, CLIP, CUPI, JIS, CIS) in a Chinese cohort. PLoS ONE 9:e88182. https://doi.org/10.1371/journal.pone.0088182

Zhao JJ et al (2015) Evaluation of eight different clinical staging systems associated with overall survival of chinese patients with hepatocellular carcinoma. Chin Med J (Engl) 128:316-321. https ://doi.org/10.4103/0366-6999.150095

Publisher's Note Springer Nature remains neutral with regard to jurisdictional claims in published maps and institutional affiliations. 